\title{
The role of soil types on the relation between individual soil properties and Fusarium wilt expression in 'Gros Michel' bananas
}

Rafael Segura Mena ( rafael.seguramena@wur.nl)

CORBANA S.A. https://orcid.org/0000-0003-1372-9928

Jetse J. Stoorvogel

Jorge A. Sandoval F.

\section{Research Article}

Keywords: Costa Rica, Disease incidence, Panama disease. Plant nutrition. Soil fertility

Posted Date: March 11th, 2021

DOI: https://doi.org/10.21203/rs.3.rs-264937/v1

License: (c) (i) This work is licensed under a Creative Commons Attribution 4.0 International License. Read Full License 


\section{Abstract}

Aims This study looks whether the response of soil management (liming and nitrogen fertilization) on the incidence of Fusarium wilt (Foc Race 1) in Gros Michel banana (Musa AAA) is influenced by soil types.

Methods The effect of inoculation with Foc Race 1 was studied in a factorial greenhouse trial with eight representative soil types of the Costa Rican banana region, two pH levels; and three levels of $\mathrm{N}$-fertilization. After an 8-week period, plant biomass, leaf area, and a disease index were measured.

Results There were significant effects of soil pH and N, and their interactions on disease expression. Low pH levels and high $\mathrm{N}$-fertilization increased the disease expression. The response to changes in soil $\mathrm{pH}$ and $\mathrm{N}$-fertilization differed considerably between the different soil types.

Conclusions Although soil pH and $\mathrm{N}$ influence Fusarium wilt in banana, each soil type differs in its response to these soil properties. This complicates the development of standard soil management strategies in terms of e.g., $\mathrm{N}$-fertilization and liming to mitigate or fight the disease.

\section{Introduction}

Fusarium wilt, also known as 'Panama disease' (caused by the soil-borne fungus Fusarium oxysporum f. sp. cubense or Foc), is one of the most critical diseases affecting banana production. Foc Race 1 devastated the subgroup Gros Michel (Musa AAA), which was the main cultivar exported from Latin America and the Caribbean (LAC) during the first half of the $20^{\text {th }}$ century (Ploetz and Churchill 2011; Pocasangre et al. 2017; Dita et al. 2018; Magdama et al. 2020). Foc Race 1 remains a serious problem in small-scale production systems in LAC where the specific traits of the Gros Michel banana are preferred (Pocasangre et al. 2011). The gradual shift of the production systems to the cultivars of the subgroup Cavendish (Musa AAA), which are resistant to Foc Race 1, was a temporary solution to the problem (Harper 1950; Stover 1961, 1962; Ploetz 1990; Perez-Vicente 2004). A new, more aggressive strain of the fungus denominated Foc Tropical Race 4 (TR4) is spreading over the world and has recently been reported in LAC (García-Bastidas et al. 2020). Most of the varieties produced in LAC, including the Gros Michel and the Cavendish subgroups, are susceptible to Foc TR4. The spread of Foc TR4 in LAC would have a tremendous impact given the economic and social importance of banana production in the region (Aurore et al. 2009; Pocasangre et al. 2011; Dita et al. 2013).

Conventional control options such as fungicides, replanting or crop rotation are ineffective in controlling or eradicating the disease (Ploetz 2006, 2015; Ordoñez et al. 2015). Other alternatives, such as the evaluation of partially resistant cultivars or breeding new resistant cultivars (Su et al. 1986; Hwang and Ko 2004; Dale et al. 2017), can take a long time to be available for practical implementation. In the short run, it is important to develop a control package that allows farmers to face the disease.

Soil management in agriculture mainly focuses on crop production and rarely considers crop disease control. However, specific soil conditions can suppress diseases in agricultural crops (Janvier et al. 2007). Managing soil properties can i) influence the soil microbiome and as a result change disease pressure or ii) influence the crop nutritional status and change the crop's predisposition to diseases (Dordas 2008; Ghorbani et al. 2008; Huber et al. 2012). Already in 1946, there were reports that liming, fertilization, and crop rotation may be a "cure" to Fusarium Wilt in Banana (Taylor (1946) cited by Jones and Morrison, 1952). Studies also included flooding of infected areas to aim for soil disinfection or a reduction of the fungus population (Stover 1961). However, through the production of chlamydospores Foc can survive extreme conditions like the anaerobic conditions under flooding (Ploetz 2015). Recently, flooding and irrigation are increasingly being attributed to also increase the spread of the disease (Salacinas 2019). After the shift from Gros Michel to the resistant Cavendish cultivars, research on Fusarium wilt control was limited for more than 30 years. However, since reports of the new and more aggressive strain Foc TR4 (Stover 1986) were published, research on controlling this disease came back. Studies show that Foc Race 1 and Foc TR4 respond in a similar way and that soil properties play an important role in conducing or suppressing the fungus in banana (Domínguez et al. 2008; Orr and Nelson 2018; Segura et al. 2021). However, the results in the literature are found to be inconsistent. This seriously hampers the translation of research results into operational management recommendations. Bananas are grown under a wide variety of agro-ecological conditions (Jaramillo and Vásquez 1990; Stoorvogel and Segura 2018). One possible reason for these inconsistencies could be that the interactions between Fusarium wilt and soil properties differ with agro-ecological conditions. Soil types have long been known to play a role in this relationship (Stotzky et al. 1961).

This study aims to evaluate the role that soil types play on the effect of liming and $\mathrm{N}$-fertilization on the incidence of Fusarium Wilt. Eight representative soil types from the Costa Rican banana region are evaluated studying the incidence of Fusarium wilt by Foc Race 1 in Gros Michel bananas in a large greenhouse experiment. The results may help to better identify the role of soil types in explaining the inconsistencies in results and to support the development soil management strategies to reduce the impact of Fusarium wilt race 1 and help to identify research strategies to similarly develop strategies to control TR4.

\section{Materials And Methods}

Banana production in Costa Rica is concentrated in the perhumid Atlantic zone (Figure 1). Soil conditions vary considerably in the area. Soil types were selected during a survey in the banana regions and they represent the variety that was found in the region (Klinkert 2014). The survey included the Caribbean lowlands, which include over 40,000 has of large intensive production of Cavendish cultivars for export (Segura et al., 2015). In addition, the Turrialba region, which has a more extensive production of Gros Michel cultivars for local markets (Ramirez et al. 2010), was incorporated into the study. Soils in the Caribbean lowlands are highly variable (Lopez and Solís 1991; Segura et al. 2015). Soils to the east of the Reventazón river (Figure 1) are predominantly sedimentary with a high clay content and high fertility. Soils to the west of the Reventazón river originate from volcanic ashes with a low clay content and medium fertility. Soils in the Turrialba region are deep, well-drained, tropical red soils with a high clay percentage and medium fertility (Dijkshoorn et al. 2005). The climate is tropical and humid with an average annual rainfall of $3000-3500 \mathrm{~mm}$ distributed throughout the year. 
Selected soils were described in situ and large topsoil samples $(0-30 \mathrm{~cm})$ were taken. Two soils were selected from the west of the Caribbean lowlands (S1 and S6), four soils were selected from the larger east of the Caribbean lowlands(S2, S3, S4 and S5), and two soils were selected from the Turrialba region (S7 and S8). The soils were analyzed for $\mathrm{pH}$, acidity, organic matter (SOM), and the concentrations of $\mathrm{Ca}, \mathrm{Mg}, \mathrm{K}, \mathrm{P}, \mathrm{Zn}, \mathrm{Cu}, \mathrm{Fe}, \mathrm{Cu}$, and $\mathrm{Mn}$, following the methodologies described by Díaz-Romeu and Hunter (1978) and (Mehlich 1984). The location and main properties of the soils are presented in Figure 1 and Table 1.

The experiment was performed in a greenhouse at the experimental station of CORBANA in La Rita (132 m.a.s.l., $10^{\circ} 15^{\prime} 54^{\prime}$ latitude N, $83^{\circ} 46^{\prime} 26^{\prime \prime}$ longitude W, maximum temperature of $35^{\circ} \mathrm{C}$ and minimum temperature of $17{ }^{\circ} \mathrm{C}$, average temperature of $28{ }^{\circ} \mathrm{C}$ with an $85 \%$ relative humidity and approx. $12 \mathrm{~h}$ of daylight). The factorial design included 8 soil types $x 2$ levels of Foc Race 1 (with and without) inoculation $x 2$ levels of soil pH $x 3$ levels of $\mathrm{N}$-fertilization $\times 3$ replications resulting in 288 pots. Two contrasting soil pH levels were tested: 1) $\mathrm{pH}_{\text {low }}$ with a pH of 5.2 or lower, and 2) $\mathrm{pH}_{\text {high }}$ with a pH equal to or higher than 6.0 . Soil $\mathrm{pH}$ was adjusted to these target levels by applying a hydrochloric acid solution $(10 \% \mathrm{HCl})$ to decrease $\mathrm{pH}$ or lime $\left(\mathrm{CaCO}_{3}\right)$ to increase soil $\mathrm{pH}$. Soil $\mathrm{pH}$ was adapted before any other treatment were applied. In each case, the acid or alkaline units of solution required to achieve the lower and the higher $\mathrm{pH}$ were calculated before liming and/or acidifying. Soil pH was analyzed before each treatment and eight days after the liming or the acidification treatments (where they prodeed). In the low pH treatment, pH levels between 4.0 and 5.1 were measured and in the high pH treatment, pH levels between 6.2 and 6.8 were measured.

Hardened, approximately 3-month-old, tissue culture banana plants (Musa AAA, subgroup Gros Michel) were used in the experiment. The plants grew in a standard potting mix before the experiment. Banana plants in young stages from tissue culture, such as the ones used in the experiment, are more sensitive to Foc infestation (Brake et al. 1995). This condition ensured the plant's response to the disease according to the treatments. Two levels of Foc Race 1 inoculation were achieved by root dipping (Dita et al. 2010; García-Bastidas et al. 2014, 2016; Ordoñez et al. 2016): 1) In I $_{0}$ a control, 30 minutes in clean water, and 2) $\ln _{1}$ : the inoculated group, 30 minutes in a solution of water with $10^{6}$ conidia $\mathrm{mL}^{-1}$ of Foc Race 1 . The fungus strain was collected from Costa Rican soils, tested, and cultivated by CORBANA's Center of Biological Control. It should be noted that plants in $\ln _{0}$ could still be infected with Foc Race 1 present in the soils. It is widely accepted that Costa Rican banana soils are infested with Foc Race 1. As the soil samples were not sterilized before the experiment in order to not disturb the soil microbiome, the plants in the control are exposed to Foc Race 1 (typically at low concentrations). Immediately after the inoculation, plants were separately planted in $2 \mathrm{~L}$ pots (one plant per pot). Three levels of $\mathrm{N}$ doses were achieved through weekly differentiated $\mathrm{N}$-fertilization with ammonium nitrate (AN, 33.5\% N): $\mathrm{N}_{\text {low }}$ with no $\mathrm{N}$ addition relying on natural $\mathrm{N}$ in the soil; 2) $\mathrm{N}_{\text {med }}$ with $0.08 \mathrm{~N} \mathrm{~g}$ plant ${ }^{-1}$ week ${ }^{-1}$ supplied through $0.24 \mathrm{~g}$ of AN plant $^{-1}$ week $^{-1}$; and 3) $\mathrm{N}_{\text {high }}$ with $0.25 \mathrm{~N} \mathrm{~g} \mathrm{plant}^{-1}$ week $^{-1}$ supplied through $0.75 \mathrm{~g}$ of AN plant week ${ }^{-1}$. These $\mathrm{N}$ doses were respectively achieved through applications of $300 \mathrm{~mL}$ of solutions of $\mathrm{AN}$ in water with concentrations of respectively $0.00 \mathrm{~g} \mathrm{~L}^{-1} \mathrm{~N}, 0.14 \mathrm{~g} \mathrm{~L}^{-1} \mathrm{~N}_{\text {and }} 0.43 \mathrm{~g} \mathrm{~L}^{-1} \mathrm{~N}$, two times week $\mathrm{N}_{\text {med }}$ emulated the average $\mathrm{N}$ requirement of plants during the first 10 weeks after planting in real field conditions. No other nutrients or agro-chemicals (e.g., fungicides, insecticides, etc.) were applied to the plants.

The experimental period was 8 weeks long and at the end of this period, total (above ground plus roots) fresh biomass ( $\mathrm{g}$ plant $\left.{ }^{-1}\right)$, the plant diameter at the base and the foliar area were measured. As the three variables were highly correlated to each other (>95\%), the data analysis was only carried out on the basis of the fresh biomass. In addition, a non-intrusive way to measure the disease according to the management of the soil properties was following the development of the wilting. The disease index (DI) was obtained adapting the McKinney's formula (McKinney 1923) that was also used by Haddad et al. (2018) and Rocha et al. (2020) in the same way. However, in this case, it was based on the number of sick plants and the wilted leaves: DI(\%)= $100 . \sum(\mathrm{f} / \mathrm{n}) \cdot(\mathrm{v} / \mathrm{x})$, where; $\mathrm{f}=$ number of sick plants; $\mathrm{n}=$ total of plants; $\mathrm{v}=$ number of leaves with symptoms; and $\mathrm{x}=$ total number of leaves (with symptoms and healthy). The presence of the typical symptoms of the wilting of the leaves in previously inoculated plants is reported as a valid element to corroborate the presence of the disease in bananas (Dita et al. 2010; García-Bastidas et al. 2014, 2016, 2020; Hung et al. 2018). Plant biomass from $I n_{0}$ and $I n_{1}$ and the wilting per plant data were analyzed using a factorial analysis of variance, which considered involved factors and their interactions: soil type, inoculation, soil $\mathrm{pH}$ and $\mathrm{N}$ for biomass, and only soil type, $\mathrm{pH}$ and $\mathrm{N}$ for wilting per plant. The differences between factors were evaluated through a Tukey's analysis.

\section{Results}

\section{Natural effect of the soil type and soil pH in not inoculated plants}

The control group $\left(\mathrm{In}_{0}\right)$ showed the effect of the soil type and the $\mathrm{pH}$ and $\mathrm{N}$ management on non (Figure 2). There were considerable differences in the mean biomass per plant according to soil type $(\mathrm{P}<0.001)$. Bananas grown on soils from the West and Turrialba showed the best mean performance with the plants grown on $\mathrm{pH}_{\text {high }}$ being significantly $(\mathrm{P}<0.001)$ larger than plants grown on $\mathrm{pH}_{\text {low. }}$. However, two soils gave more biomass in plants from $\mathrm{pH}$ low. The $\mathrm{N}$ dose did not significantly affect the biomass over the eight soils $(P \geq 0.730)$. The effect of $\mathrm{N}$ fertilization differed per soil type where in some cases the increased nitrogen levels resulted in an improved performance but in other cases there was a decline in the performance with the increases in Nitrogen. It is likely that these differences are related to the residual $\mathrm{N}$ in the original soil samples.

\section{Soil pH and $\mathrm{N}$ interactions and plant biomass and disease index (DI)}

Inoculation with Foc reduced plant biomass. Biomass in $\ln _{1}$ was significantly lower than biomass in $\ln _{0}$ for almost all the soil types and $\mathrm{pH}$ levels (Table 2 ) The effect of the inoculation expressed as a decline in plant biomass was higher in $\mathrm{pH}_{\text {low }}(61.6 \%)$ in contrast to $\mathrm{pH}_{\text {high }}(50.8 \%)$. However, $\mathrm{pH}$ differences resulted in a very different response to the inoculation of the disease for the different soil types as presented in Figure 3 . The figure shows that for most soils a 
$\mathrm{pH}$ increase led to a greater biomass for both the control and the inoculated group. However, the direction and the length of the arrows differ indicating that there is a considerable effect of the soil.

Inoculation led to a significant decline in almost all soil - $\mathrm{N}$ dose combinations (Table 3 ). With increasing $\mathrm{N}$-fertilization, typically, the decline in biomass due to inoculation increased. In addition, the biomass according to the interactions of the inoculation with the soil type, the $\mathrm{pH}$ level and the $\mathrm{N}$ dose was also significant. A higher effect of the interaction of the soil and the inoculation was evident in all soils. The response of the Figure 4 shows a sample of plants grown in soils from the three regions. The detrimental effect of the interaction between $\mathrm{pH}_{\text {low }}$ and inoculation was evident in plants from the three regions. In spite of following the trend of a higher biomass in $\mathrm{pH}_{\text {high }}$, the mean biomass in $\mathrm{In}_{1}$ was contrastingly lower against the control for both $\mathrm{pH}$ levels. The interaction of the inoculation and the $\mathrm{N}$ dose was expressed in different trends according the soil type and pH levels and the average biomass (Figure 5). The lower biomass in the $\mathrm{N}_{\text {high }}$ and $\mathrm{pH}_{\text {low }}$. From the possible combinations, the higher wilting took place in $\mathrm{N}_{\text {high }}$ and $\mathrm{pH}_{\text {high }}$.

The single effect of soil pH was significant in the DI expression with a higher average of wilting in $\mathrm{pH}_{\text {high. }}$ The higher $\mathrm{DI}$ is offset by the increased performance of the plant at $\mathrm{pH}_{\text {high }}$ still leading to a net benefit of the increased $\mathrm{pH}$. The $\mathrm{DI}$ according the $\mathrm{N}$ doses was not significant, and its trend was more erratic. Plants from $\mathrm{pH}_{\text {high }}$ remained more biomass and expressed a lower DI. The interaction $\mathrm{pH} \times \mathrm{N}$ was significant $(\mathrm{P} \leq 0.0040)$ in the $\mathrm{DI}$ and average biomass (Figure 6). There was a lower biomass in $\mathrm{N}_{\text {high }}$ and $\mathrm{pH}_{\text {low. }}$. From the possible combinations, more wilting took place in $\mathrm{N}_{\text {high }}$ and $\mathrm{pH}_{\text {high }}$. The single effect of soil $\mathrm{pH}$ was significant with a higher $\mathrm{DI}$ in $\mathrm{pH}_{\text {high }}$. The $\mathrm{DI}$ according to the $\mathrm{N}$ doses was not significant and its trend was more erratic. Plants from $\mathrm{pH}_{\text {high }}$ maintained more biomass and expressed a lower DI.

\section{Discussion}

Soil type were found to have a strong effect on plant performance under natural (not inoculated) and inoculated conditions. Losses in biomass in $\mathrm{n}_{1}$ can be attributed to the detrimental effect of Fusarium wilt on the plants. Due to the incidence, biomass in the inoculated plants was lower because of the loss of the tissue it produced in the plant. Soil $\mathrm{pH}_{\text {high }}$ increased the biomass per plant for both $\mathrm{In}_{0}$ and $\mathrm{In}_{1}$ treatments. Besides, $\mathrm{pH} x$ inoculation interactions on the effect of the disease was stronger in $\mathrm{pH}_{\text {low. }}$. This they could imply a direct (Almeida et al. 2018), indirect effect, or both, of soil pH on the incidence of the disease. The role of $\mathrm{pH}$ as an indicator of soil health in banana and its influence in soil suppressiveness is known (Pattison et al. 2008; Geense et al. 2015; Segura et al. 2015). Low soil pH (less than 5.2) apparently can stimulate pathogen activity in the soil due to a detrimental effect on soil diversity. However, this was not evaluated in this trial. The lower pH also limits plant nutrient and water uptake (White 2012). This effect can increase banana predisposition to diseases led both by a higher Foc activity and a limited capacity to perform physiological processes against the infestation.

Despite the differences according to the interaction of soil type and inoculation, and the general effect of pH on plant response, the detrimental interaction of lower $\mathrm{pH}$ x inoculation was higher in various soil types. The highest effect of the disease expressed as a lower biomass found in the eastern area could be due to the specific characteristics of these. Although all of them have a high fertility, plants from those soils were more sensible to the disease, especially in $\mathrm{pH}_{\text {low }}$ The soil type as a package can play a natural role in plant status and it can define the plant's predisposition to the disease. Previous reports indicated that chemical and physical soil conditions would be linked to soil conduciveness of Fusarium wilt (Scher 1980; Domínguez et al. 2008). However, analyzing the interaction of soil properties and the disease in one single soil can lead to misunderstandings and inconsistent conclusions. Interactions of the soil type with $\mathrm{pH}, \mathrm{N}$ and other abiotic conditions, such as the higher clay content, Fe and $\mathrm{Mn}$, for instance, would be involved in the plant's response. This knowledge is crucial when considering soil management to deal with or control Fusarium wilt in banana.

The plant's response to the disease can be ruled by the particular ecological condition of each soil. Soils with a lower concentration of SOM in the eastern region, for instance, showed the highest detrimental effect of the disease. In the western region, plant response was erratic according to the inoculation. In fact, the best plant performance under infected and $\mathrm{pH}_{\text {low }}$ conditions took place with the highest soil SOM ( 6 , S7 and S8). $\mathrm{Plants}$ in $\mathrm{pH}$ low were more predisposed to Fusarium wilt in all tested soils. Results allow us to define different degrees of risk to the disease, according to the study regions. However even in a same banana region, the magnitude of the response to the disease according to the management of $\mathrm{pH}$ and $\mathrm{N}$ differed depending on the soil type. Nevertheless, practices such as maintaining a higher $\mathrm{pH}$ and increasing SOM through management appear to be preventive measures that can decrease plant predisposition to the disease. This seems to be a standard recommendation for all banana locations could be complex or not applicable. With this information, strategies based on soil management to prevent and deal with Foc can be implemented, in this case specifically for the Costa Rican reality.

The interaction of soil type with $\mathrm{pH}$ and $\mathrm{N}$ management in the disease expression should be studied thoroughly. How and where this interaction is more significant in the disease can define the strategy that should be implemented in crop management. Soil $\mathrm{pH}_{\text {low }}$ and $\mathrm{N}_{\text {high }}$ predisposed the plant to be more easily infected and more affected by the disease. A higher level of wilting was found with the $\mathrm{N}$ application in both $\mathrm{pH}$ levels and it was more significant in $\mathrm{pH}_{\text {low }}$. It appears that soil $\mathrm{pH}$ is a primary factor in the plant's predisposition to the disease in most of the studied soil types. $\mathrm{N}$ inputs have important impacts in soil conditions, but the plant's response to the disease was more erratic according to this soil property. At the same time, $\mathrm{N}$ ammonia sources are recognized as a main cause for a drop in $\mathrm{pH}$ in soils from agricultural lands. Therefore, an integral management of soil properties to alleviate or prevent Fusarium wilt should include $\mathrm{pH}$ management and choosing less acidity $\mathrm{N}$ sources. In addition, it is necessary to include a soil $\mathrm{N}$ analysis in order to define the $\mathrm{N}$ recommendation for banana plantations.

More integral soil conditions can be playing a role in plant response to the disease. Furthermore, the role that the soil type played in the plant's response to de disease was evident. Although it agrees with the response in terms of suppression or conduction of the disease according to the soil type in Australia (Bowen et al. 2019), the results that we found allowed us to see a complex interaction of the soil type, its properties and the incidence of the disease. The influence of specific soil properties linked to the soil type (chemical, physical and microbiological) in each type of soil or each banana region can be part of the scenario of the natural banana's response to the disease. This could be the reason why previous studies have shown an erratic behavior of the disease according to soil

Page $4 / 11$ 
management. Probably these results could depend on the region where plantations are established in the different banana locations in Costa Rica. The specific study of at least soil type and its conditions on banana predisposition to Fusarium wilt in each location or banana region is necessary to better understand the role of soil conditions in Fusarium wilt in bananas. Even ecological and environmental aspects of each region can be playing a role in the incidence of the disease.

\section{Conclusions}

Soil properties like $\mathrm{pH}$ and $\mathrm{N}$ play an important role in banana predisposition to Fusarium wilt and in the disease incidence. However, this relation is strongly influenced by soil type, i.e., other properties. This complexity clearly hampers the development of uniform management recommendations. Nevertheless, general trends are found. An increase in soil pH supports, in almost all cases, the suppression of Fusarium wilt. For the development of more specific soil management strategies, it appears to be necessary to view the soil as an integral system of physical, chemical, and biological properties rather than looking at individual soil properties with their thresholds. This complexity could be the cause for the inconsistencies that were found in the literature with respect to the role of soil properties in suppressing or conducing Fusarium wilt in banana.

\section{Declarations}

Ethical statement: This manuscript is not submitted to another journal. The manuscript is original, and it is not published elsewhere partially or in full, in any form or language. Besides, it does not concern an expansion of previous work. The study is not split up into several parts to increase the quantity of submissions and submitted to various journals or to one journal over time. Results are presented clearly, honestly, and without fabrication, falsification, or inappropriate data manipulation. Data was collected from the greenhouse experiment and managed with statistical software with total honestly and transparence. No data, text, or theories by others are presented as if they were the author's own. All collected data, and the performed analysis are available (as a supplementary file). Proper acknowledgements to other works are given. This piece of work respects third parties' rights such as copyright and/or moral rights

Author's contribution statement: All the authors took part in conceptualization of the research and editing the manuscript and consent its publication. RS and JAS performed the greenhouse experiment in Costa Rica. RS and JJS performed the results analysis and RS wrote the manuscript. JSS and JS made important inputs to improve the final version of the manuscript.

Acknowledgments: Susan Klinkert and Raphael Hürliman are acknowledged for respectively supporting soil characterization and sampling in the Costa Rican experiment. Claudiana Carr, MSc. from the CORBANA's Research Center is acknowledged for supporting and supervision plant inoculation with Foc Race 1. Fabio Blanco MSc. is gratefully acknowledged for the support with the experimental design and the statistical analysis of the results. The study is financially supported by CORBANA and the Interdisciplinary Research and Education Fund (INREF) of Wageningen University.

\section{References}

Almeida NO, Teixeira RA, Carneiro FA, et al (2018) Occurrence and correlations of nematodes, Fusarium oxysporum and edaphic factors on banana plantations. J Phytopathol 166:265-272. https://doi.org/10.1111/jph.12683

Aurore G, Parfait B, Fahrasmane L (2009) Bananas, raw materials for making processed food products. Trends Food Sci Technol 20:78-91. https://doi.org/10.1016/j.tifs.2008.10.003

Bowen A, Orr R, McBeath AV, et al (2019) Suppressiveness or conduciveness to Fusarium wilt of bananas differs between key Australian soils. Soil Res 57:158. https://doi.org/10.1071/SR18159

Brake V, Pegg K, Irwin J, Chaseling J (1995) The influence of temperature, inoculum level and race of Fusarium oxysporum f.sp. cubense on the disease reaction of banana cv. Cavendish. Aust J Agric Res 46:673. https://doi.org/10.1071/AR9950673

Dale J, Paul J-Y, Dugdale B, Harding R (2017) Modifying Bananas: From Transgenics to Organics? Sustainability 9:333-346.

https://doi.org/10.3390/su9030333

Díaz-Romeu R, Hunter A (1978) Metodologías de muestreo de suelos, análisis químico de suelos y tejido vegetal y de investigaciones en invernadero. CATIE, Turrialba, Costa Rica

Dijkshoorn JA, Hunting JRM, Tempel P (2005) Update of the 1:5 million Soil and Terrain Database for Latin America and the Caribbean (SOTERLAC; version 2.0). ISRIC - World Soil Information, Wageningen, The Netherlands

Dita M, Barquero M, Heck D, et al (2018) Fusarium Wilt of Banana: Current Knowledge on Epidemiology and Research Needs Toward Sustainable Disease Management. Front Plant Sci 9:1468. https://doi.org/10.3389/fpls.2018.01468

Dita MA, Garming H, Bergh I, et al (2013) Banana in Latin America and the Caribbean: Current State, Challenges and Perspectives. Acta Hortic 896:365-380

Dita MA, Waalwijk C, Buddenhagen IW, et al (2010) A molecular diagnostic for tropical race 4 of the banana fusarium wilt pathogen. Plant Pathol 59:348-357. https://doi.org/10.1111/j.1365-3059.2009.02221.x 
Domínguez J, Negrín MA, Rodríguez CM (2008) Soil Potassium Indices and Clay-Sized Particles affecting Banana-Wilt Expression Caused by Soil Fungus in Banana Plantation Development on Transported Volcanic Soils. Commun Soil Sci Plant Anal 39:397-412. https://doi.org/10.1080/00103620701826522

Dordas C (2008) Role of nutrients in controlling plant diseases in sustainable agriculture. A review. Agron Sustain Dev 28:33-46.

https://doi.org/10.1051/agro:2007051

García-Bastidas F, Laghari HB, Akkary MY, et al (2016) First Report of Fusarium oxysporum f. sp. cubense Tropical Race 4 Causing Panama Disease in Cavendish Bananas in Pakistan and Lebanon. Plant Dis 100:209. https://doi.org/10.1094/PDIS-12-14-1356-PDN

García-Bastidas FA, Ordóñez N, Konkol J, et al (2014) First Report of Fusarium oxysporum f. sp. cubense Tropical Race 4 Associated with Panama Disease of Banana outside Southeast Asia. Plant Dis 98:694-694. https://doi.org/10.1094/PDIS-09-13-0954-PDN

García-Bastidas FA, Quintero-Vargas JC, Ayala-Vasquez M, et al (2020) First Report of Fusarium Wilt Tropical Race 4 in Cavendish Bananas Caused by Fusarium odoratissimum in Colombia. Plant Dis 104:994-994. https://doi.org/10.1094/PDIS-09-19-1922-PDN

Geense P, Pattison AB, Kukulies TL, et al (2015) Can Changes in Soil Properties in Organic Banana Production Suppress Fusarium Wilt? Nat Resour 06:181195. https://doi.org/10.4236/nr.2015.63017

Ghorbani R, Wilcockson S, Koocheki A, Leifert C (2008) Soil management for sustainable crop disease control: a review. Environ Chem Lett 6:149-162. https://doi.org/10.1007/s10311-008-0147-0

Haddad F, Rocha LS, Soares ACF, et al (2018) Management of Fusarium wilt of bananas in Minas Gerais, Brazil. Acta Hortic $137-146$.

https://doi.org/10.17660/ActaHortic.2018.1196.16

Harper JL (1950) Studies in the resistance of certain varieties of banana to panama disease. Plant Soil 2:383-394. https://doi.org/10.1007/BF01343358

Huber D, Römheld V, Weinmann M (2012) Relationship between Nutrition, Plant Diseases and Pests. In: Marschner's Mineral Nutrition of Higher Plants.

Elsevier, pp 283-298

Hung TN, Hung NQ, Mostert D, et al (2018) First Report of Fusarium Wilt on Cavendish Bananas, Caused by Fusarium oxysporum f. sp. cubense Tropical Race 4 (VCG 01213/16), in Vietnam. Plant Dis 102:448-448. https://doi.org/10.1094/PDIS-08-17-1140-PDN

Hwang S-C, Ko W-H (2004) Cavendish Banana Cultivars Resistant to Fusarium Wilt Acquired through Somaclonal Variation in Taiwan. Plant Dis 88:580-588. https://doi.org/10.1094/PDIS.2004.88.6.580

Janvier C, Villeneuve F, Alabouvette C, et al (2007) Soil health through soil disease suppression: Which strategy from descriptors to indicators? Soil Biol Biochem 39:1-23. https://doi.org/10.1016/j.soilbio.2006.07.001

Jaramillo R, Vásquez A (1990) Manual de procedimiento para la presentación de estudios detallados de suelos y clasificación de tierras para el cultivo de banano

Jones CF, Morrison PC (1952) Evolution of the Banana Industry of Costa Rica. Econ Geogr 28:1-19

Klinkert S (2014) A Mechanistic approach to soil variability at different scale levels: A case study for the Atlantic Zone of Costa Rica. Wageningen UR, The Netherlands

Lopez A, Solís P (1991) Contenidos e interacciones de los nutrimentos en tres zonas bananeras de Costa Rica. CORBANA 15:15-25

Magdama F, Monserrate-Maggi L, Serrano L, et al (2020) Genetic Diversity of Fusarium oxysporum f. sp. cubense, the Fusarium Wilt Pathogen of Banana, in Ecuador. Plants 9:1133. https://doi.org/10.3390/plants9091133

McKinney RH (1923) Influence of soil temperature and moisture on infection of wheat seedlings by Helminthosporium sativum. J Ag Res 6:195-218

Mehlich A (1984) Mehlich 3 soil test extractant: A modification of Mehlich 2 extractant. Commun Soil Sci Plant Anal 15:1409-1416.

https://doi.org/10.1080/00103628409367568

Ordoñez N, García-Bastidas F, Laghari HB, et al (2016) First Report of Fusarium oxysporum f. sp. cubense Tropical Race 4 Causing Panama Disease in Cavendish Bananas in Pakistan and Lebanon. Plant Dis 100:209. https://doi.org/10.1094/PDIS-12-14-1356-PDN

Ordoñez N, Seidl MF, Waalwijk C, et al (2015) Worse Comes to Worst: Bananas and Panama Disease-When Plant and Pathogen Clones Meet. PLOS Pathog 11:e1005197. https://doi.org/10.1371/journal.ppat.1005197

Orr R, Nelson PN (2018) Impacts of soil abiotic attributes on Fusarium wilt, focusing on bananas. Appl Soil Ecol 132:20-33.

https://doi.org/10.1016/j.apsoil.2018.06.019

Pattison AB, Moody PW, Badcock KA, et al (2008) Development of key soil health indicators for the Australian banana industry. Appl Soil Ecol 40:155-164. https://doi.org/10.1016/j.apsoil.2008.04.002 
Perez-Vicente L (2004) Fusarium wilt (Panama disease) of bananas: an updating review of the current knowledge on the disease and its causal agent. Fitosanidad 8:27-38

Ploetz RC (1990) Vegetative compatibility in Fusarium Oxysporum f.sp.cubense: Classifying previosly noncharacterized strains. Acta Hortic $699-706$

Ploetz RC (2006) Fusarium Wilt of Banana Is Caused by Several Pathogens Referred to as Fusarium oxysporum f. sp. cubense. Phytopathology 96:653-656. https://doi.org/10.1094/PHYTO-96-0653

Ploetz RC (2015) Management of Fusarium wilt of banana: A review with special reference to tropical race 4. Crop Prot 73:7-15.

https://doi.org/10.1016/j.cropro.2015.01.007

Ploetz RC, Churchill CL (2011) Fusarium Wilt: the Banana Disease that Refuses to Go Away. Acta Hortic 897:519-526

Pocasangre LE, Perez-Vicente L, Ferris H (2017) Organic Banana Disease Management. In: Plant Diseases and Their Management in Organic Agriculture. The American Phytopathological Society, pp 354-365

Pocasangre LE, Ploetz RC, Molina AB, et al (2011) Raising Awareness of the Threat of Fusarium Wilt Tropical Race 4 in Latin America and the Caribbean. Acta Hortic 897:331-337. https://doi.org/10.17660/ActaHortic.2011.897.45

Ramirez C, Tapia A, Calvo P (2010) Quality evaluation of the banana of height produced in the 421 area of Turrialba, Costa Rica. Intersedes XI:

Rocha A de J, Ferreira M dos S, Rocha L de S, et al (2020) Interaction between Fusarium oxysporum f. sp. cubense and Radopholus similis can lead to changes in the resistance of banana cultivars to Fusarium wilt. Eur J Plant Pathol. https://doi.org/10.1007/s10658-020-02081-y

Salacinas MA (2019) Managing Panama Disease in the Philippines. Wageningen, The Netherlands

Scher FM (1980) Mechanism of Biological Control in a Fusarium-Suppressive Soil. Phytopathology 70:412. https://doi.org/10.1094/Phyto-70-412

Segura RA, Serrano E, Pocasangre L, et al (2015) Chemical and microbiological interactions between soils and roots in commercial banana plantations (Musa AAA, cv. Cavendish). Sci Hortic 197:66-71. https://doi.org/10.1016/j.scienta.2015.10.028

Segura RA, Stoorvogel JJ, García-Bastidas F, et al (2021) Evaluating the potential of soil management to reduce the effect of Fusarium oxysporum f. sp. cubense in banana (Musa AAA). Eur J Plant Pathol Accepted

Stoorvogel JJ, Segura RA (2018) Nutrition and soil management in banana cultivation. In: Kema GHJ, Drenth A (eds) Burleigh Dodds Series in Agricultural Science. Burleigh Dodds Science Publishing, pp 223-234

Stotzky G, Dawson JE, Martin RT, Ter Kuile CHH (1961) Soil Mineralogy as Factor in Spread of Fusarium Wilt of Banana. Science 133:1483-1485.

https://doi.org/10.1126/science.133.3463.1483

Stover RH (1962) Fusarial wilt (panama disease) of bananas and other Musa species. The Common wealth Mycological Institute, Kew Surrey

Stover RH (1961) Studies on Fusarium Wilt of Bananas. I. Field Control. Can J Bot 39:197-206

Stover RH (1986) Disease management strategies and the survival of the banana industry. Annu Rev Phytopathol 24:83-91

Su H, Hwang S-C, Ko W-H (1986) Fusarial Wilt of Cavendish Bananas in Taiwan. Plant Dis 70:814-818

White PJ (2012) Ion Uptake Mechanisms of Individual Cells and Roots. In: Marschner's Mineral Nutrition of Higher Plants. Elsevier, pp 7-47

\section{Tables}

Table 1. Soil properties for eight representative soil types from the Costa Rican banana region. 


\begin{tabular}{|c|c|c|c|c|}
\hline \multirow[t]{3}{*}{ Code } & \multicolumn{2}{|c|}{ Location } & \multirow[t]{3}{*}{$\mathrm{pH}$} & Acidity \\
\hline & & N. & & \\
\hline & W. Longitud & Latitude & & $\mathrm{Cl}$ \\
\hline \multicolumn{5}{|l|}{ West } \\
\hline $\mathrm{S} 1^{\mathrm{a}}$ & $83^{\circ} 48^{\prime \prime} 49$ & $10^{\circ} 17^{\prime \prime} 50$ & 5.7 & 0.20 \\
\hline$S 6^{a}$ & $83^{\circ} 45^{\prime \prime} 15$ & $10^{\circ} 25^{\prime \prime} 40$ & 5.3 & 0.36 \\
\hline \multicolumn{5}{|l|}{ East } \\
\hline $\mathrm{S} 2^{\mathrm{b}}$ & $83^{\circ} 17^{\prime \prime} 06$ & $09^{\circ} 58^{\prime \prime} 48$ & 6.6 & 0.03 \\
\hline $\mathrm{S} 3^{\mathrm{c}}$ & $83^{\circ} 42^{\prime \prime} 17$ & $10^{\circ} 24^{\prime \prime} 49$ & 4.9 & 2.61 \\
\hline$S 4^{d}$ & $82^{\circ} 48^{\prime \prime} 09$ & $09^{\circ} 40^{\prime \prime} 16$ & 6.1 & 0.52 \\
\hline$S 5^{d}$ & $82^{\circ} 50^{\prime \prime} 16$ & $09^{\circ} 37^{\prime \prime} 15$ & 6.1 & 0.11 \\
\hline \multicolumn{5}{|l|}{ Turrialba } \\
\hline$S 7^{\mathrm{e}}$ & $83^{\circ} 38^{\prime \prime} 58$ & $09^{\circ} 57^{\prime \prime} 02$ & 5.6 & 0.24 \\
\hline$S 8^{f}$ & $83^{\circ} 42^{\prime \prime} 54$ & $09^{\circ} 57^{\prime \prime} 22$ & 6.1 & 0.05 \\
\hline
\end{tabular}

Table 2 Decline in biomass as response of 'Gros Michel' banana plants to the inoculation with Foc

Race 1 according to two soil pH levels in eight soils types from the Costa Rican banana region.

\begin{tabular}{|c|c|c|c|c|c|c|c|c|c|}
\hline \multirow[t]{2}{*}{ Soil type } & \multicolumn{2}{|c|}{$\mathrm{pH}_{\text {low }}<5.2$} & \multirow{2}{*}{$\begin{array}{c}\text { decline } \\
\%\end{array}$} & \multirow[t]{2}{*}{$\mathrm{P}<\mathrm{f}$} & \multicolumn{2}{|c|}{$\mathrm{pH}_{\text {high }}>6.0$} & \multirow{2}{*}{$\begin{array}{c}\text { Decline } \\
\%\end{array}$} & \multirow[t]{2}{*}{$P<f$} & \multirow[t]{2}{*}{$\mathrm{pH}$ effect on decline } \\
\hline & $\operatorname{In}_{0}$ & $\operatorname{In}_{1}$ & & & $\operatorname{In}_{0}$ & $\mathrm{In}_{1}$ & & & \\
\hline \multicolumn{10}{|l|}{ West } \\
\hline S1 & 38.5 & 5.6 & 85.6 & $<0.001$ & 32.3 & 12.6 & 60.9 & $<0.001$ & 24.7 \\
\hline S6 & 21.6 & 11.5 & 47.1 & 0.008 & 30.3 & 18.0 & 40.6 & 0.001 & 6.4 \\
\hline \multicolumn{10}{|l|}{ East } \\
\hline $\mathrm{S} 2$ & 13.0 & 6.5 & 50.2 & 0.085 & 26.0 & 11.0 & 57.6 & 0.001 & -7.5 \\
\hline S3 & 12.1 & 7.2 & 40.7 & 0.193 & 42.1 & 24.4 & 41.9 & $<0.001$ & -1.2 \\
\hline S4 & 4.4 & 1.7 & 61.7 & 0.477 & 27.8 & 15.6 & 43.7 & 0.002 & 18.0 \\
\hline S5 & 12.5 & 2.5 & 79.9 & 0.009 & 40.5 & 23.7 & 41.4 & $<0.001$ & 38.5 \\
\hline \multicolumn{10}{|l|}{ Turrialba } \\
\hline S7 & 40.5 & 10.3 & 74.5 & $<0.001$ & 37.1 & 16.5 & 55.5 & $<0.001$ & 18.9 \\
\hline S8 & 27.3 & 12.9 & 52.7 & $<0.001$ & 39.0 & 13.8 & 64.7 & $<0.001$ & -11.9 \\
\hline Mean & 21.2 & 7.3 & 61.6 & 0.016 & 34.4 & 17.0 & 50.8 & 0.001 & -9.1 \\
\hline
\end{tabular}

Table 3 Decline in biomass as response of Gros Michel banana plants to the inoculation with Foc Race 1 according to three Nitrogen levels in eight soils types from the Costa Rican banana region.

\begin{tabular}{|c|c|c|c|c|c|c|c|c|c|c|c|c|c|}
\hline \multirow[t]{2}{*}{ Soil type } & \multicolumn{2}{|c|}{$\mathrm{N}_{\text {low }}$} & \multirow{2}{*}{$\begin{array}{c}\text { decline }^{1} \\
\%\end{array}$} & \multirow[t]{2}{*}{$\mathrm{P}<\mathrm{f}$} & \multicolumn{2}{|c|}{$\mathrm{N}_{\text {med }}$} & \multirow{2}{*}{$\begin{array}{c}\text { decline }^{2} \\
\%\end{array}$} & \multirow{2}{*}{$\begin{array}{c}\text { P f } \\
\%\end{array}$} & \multicolumn{2}{|c|}{$\mathrm{N}_{\text {high }}$} & \multirow{2}{*}{$\begin{array}{c}\text { decline }^{3} \\
\%\end{array}$} & \multirow[t]{2}{*}{$\mathrm{P}<\mathrm{f}$} & \multirow{2}{*}{$\begin{array}{c}\mathrm{N} \text { effect on } \\
\text { decline } \\
\left(\mathrm{N}_{\text {low vs }}\right. \\
\left.\mathrm{N}_{\text {med }}, \mathrm{N}_{\text {high }}\right)\end{array}$} \\
\hline & $\mathrm{In}_{0}$ & $\mathrm{In}_{1}$ & & & $\mathrm{In}_{0}$ & $\mathrm{In}_{1}$ & & & $\mathrm{In}_{0}$ & $\mathrm{In}_{1}$ & & & \\
\hline \multicolumn{14}{|l|}{ West } \\
\hline S1 & 36.5 & 10.1 & 72.4 & $<0.001$ & 38.5 & 7.8 & 79.7 & $<0.001$ & 31.4 & 9.5 & 69.9 & $<0.001$ & -2.4 \\
\hline S6 & 26.4 & 15.7 & 40.8 & 0.026 & 22.4 & 19.9 & 11.2 & 0.604 & 29.1 & 8.6 & 70.4 & $<0.001$ & 0.0 \\
\hline \multicolumn{14}{|l|}{ East } \\
\hline S2 & 18.5 & 12.5 & 32.7 & 0.211 & 15.4 & 8.5 & 44.6 & 0.156 & 24.6 & 5.2 & 78.7 & $<0.001$ & -29.0 \\
\hline S3 & 24.5 & 19.2 & 21.6 & 0.274 & 26.5 & 16.5 & 37.8 & 0.039 & 30.2 & 11.7 & 61.4 & $<0.001$ & -28.0 \\
\hline $\mathrm{S} 4$ & 14.4 & 11.2 & 22.3 & 0.505 & 17.9 & 9.2 & 48.4 & 0.074 & 15.9 & 5.5 & 65.2 & 0.033 & -34.4 \\
\hline S5 & 27.6 & 11.0 & 60.1 & 0.001 & 26.9 & 11.3 & 57.8 & 0.002 & 25.1 & 17.1 & 32.1 & 0.096 & 15.2 \\
\hline \multicolumn{14}{|l|}{ Turrialba } \\
\hline S7 & 35.0 & 15.9 & 54.6 & 0.001 & 41.4 & 14.4 & 65.2 & $<0.001$ & 40.2 & 10.0 & 75.0 & $<0.001$ & -15.5 \\
\hline S8 & 33.0 & 12.8 & 61.2 & $<0.001$ & 31.6 & 16.5 & 47.8 & 0.002 & 34.8 & 10.6 & 69.5 & $<0.001$ & 2.6 \\
\hline Mean & 27.0 & 13.5 & 49.9 & 0.003 & 27.6 & 13.0 & 52.8 & $<0.001$ & 28.9 & 9.8 & 66.2 & $<0.001$ & -9.6 \\
\hline
\end{tabular}

\section{Figures}




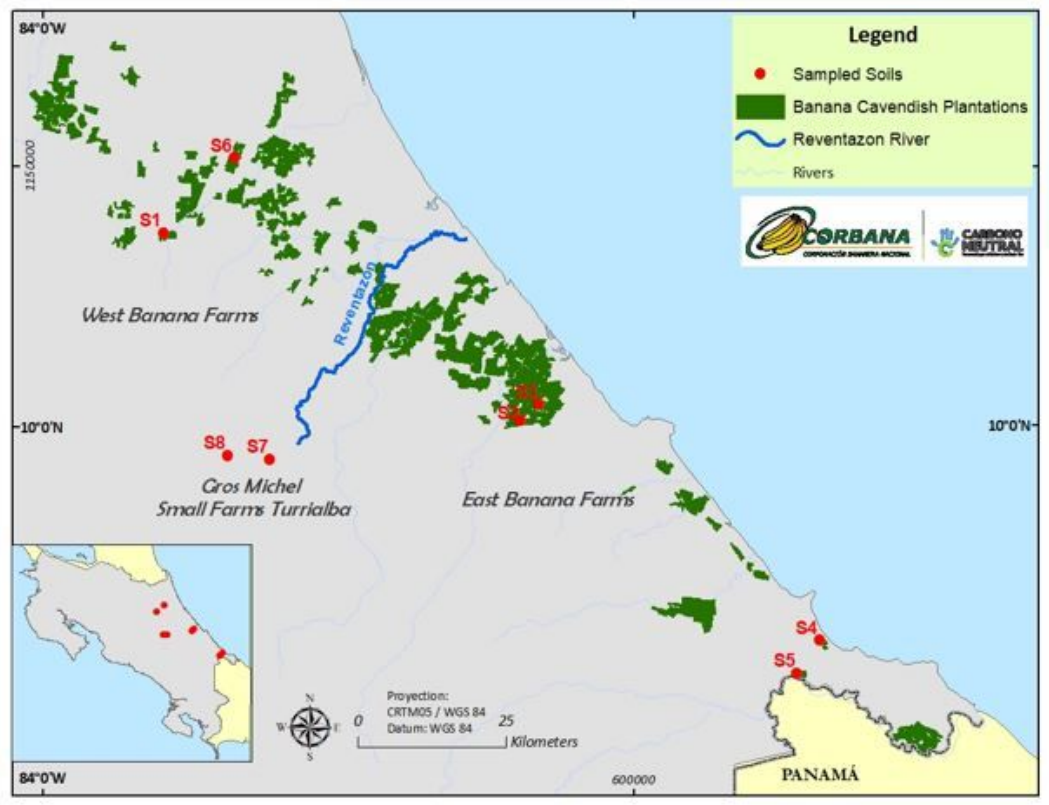

Figure 1

Sample points of eight representative soil types from the Costa Rican banana region.

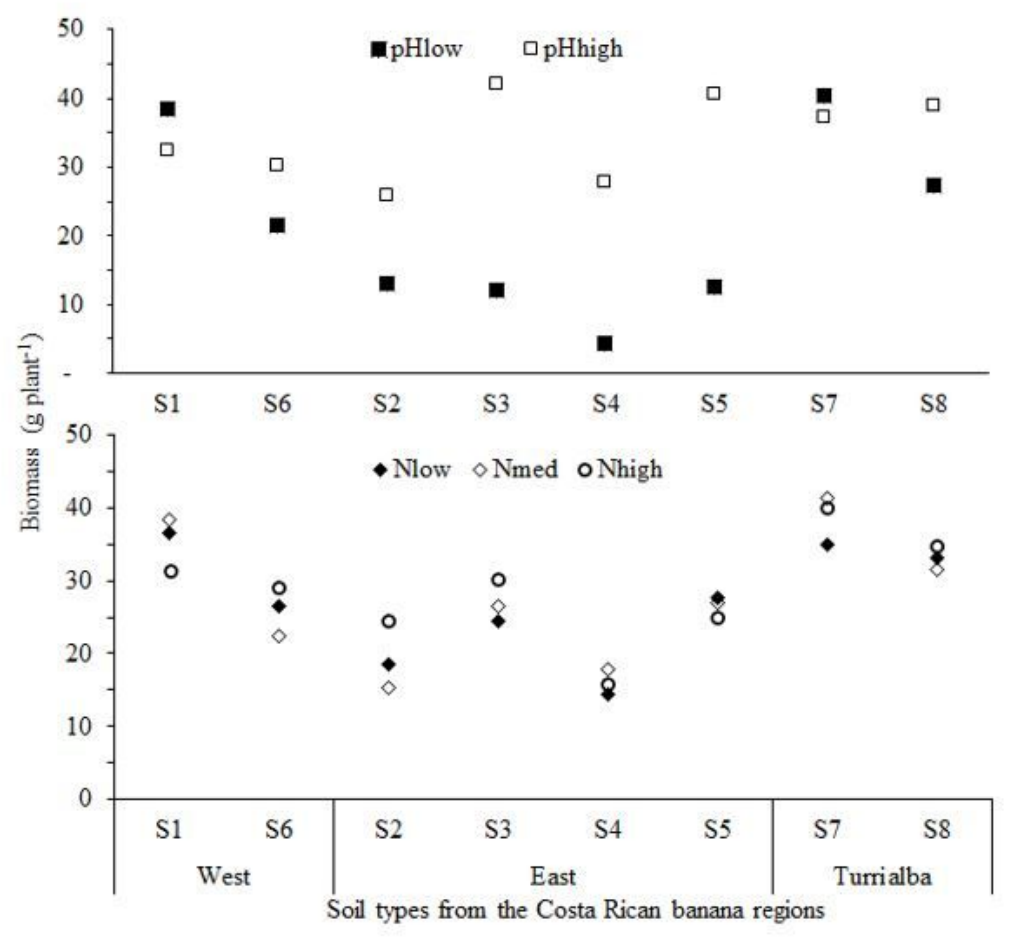

\section{Figure 2}

Biomass from control, not inoculated $(\operatorname{In} 0)$ Gross Michel (Musa AAA) banana plants grown in a greenhouse experiment at two soil pH levels and three $\mathrm{N}$ levels in eight representative soil types from the Costa Rican banana region. 


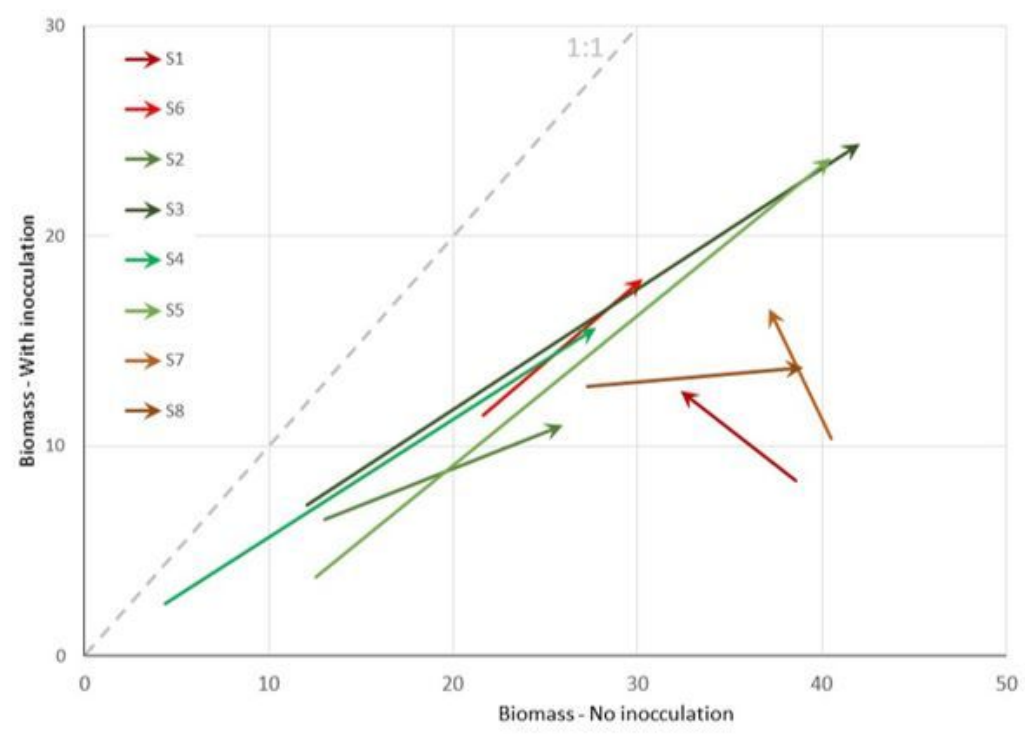

\section{Figure 3}

The effect of an increase of soil pH on the effect of Fusarium wilt (Foc Race 1) on the leaf area of Gros Michel (Musa AAA) banana plants in a pot experiment with 8 soil types from Costa Rican banana regions. The arrows represent the effect of the $\mathrm{pH}$ increases (representing liming).
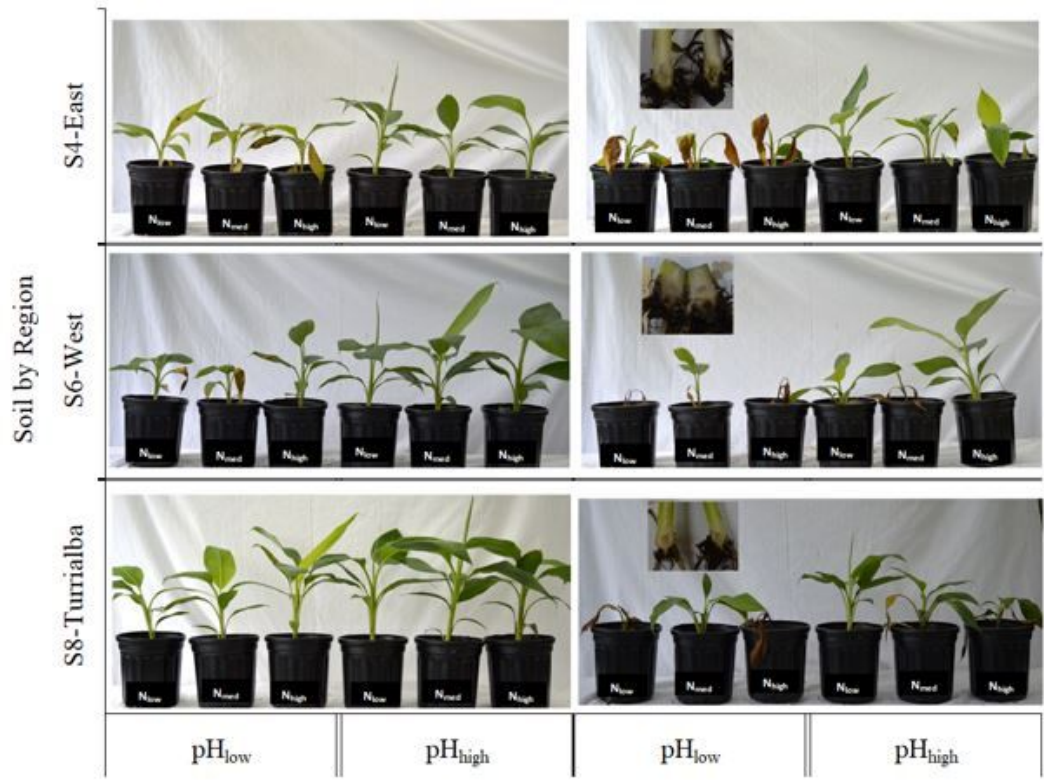

Control $\left(\mathrm{In}_{0}\right)$

Foc Race 1 inoculated $\left(\ln _{1}\right)$

\section{Figure 4}

Condition of inoculated $(\operatorname{In} 1)$ and not inoculated $(\ln 0)$ Gross Michel banana plants (Musa AAA) grown in three representative soil types from the Costa Rican banana region (east, west and turrialba) under two $\mathrm{pH}$ levels (pHlow and pHhigh) and three $\mathrm{N}$ doses (Nlow, Nmed and Nhigh). 


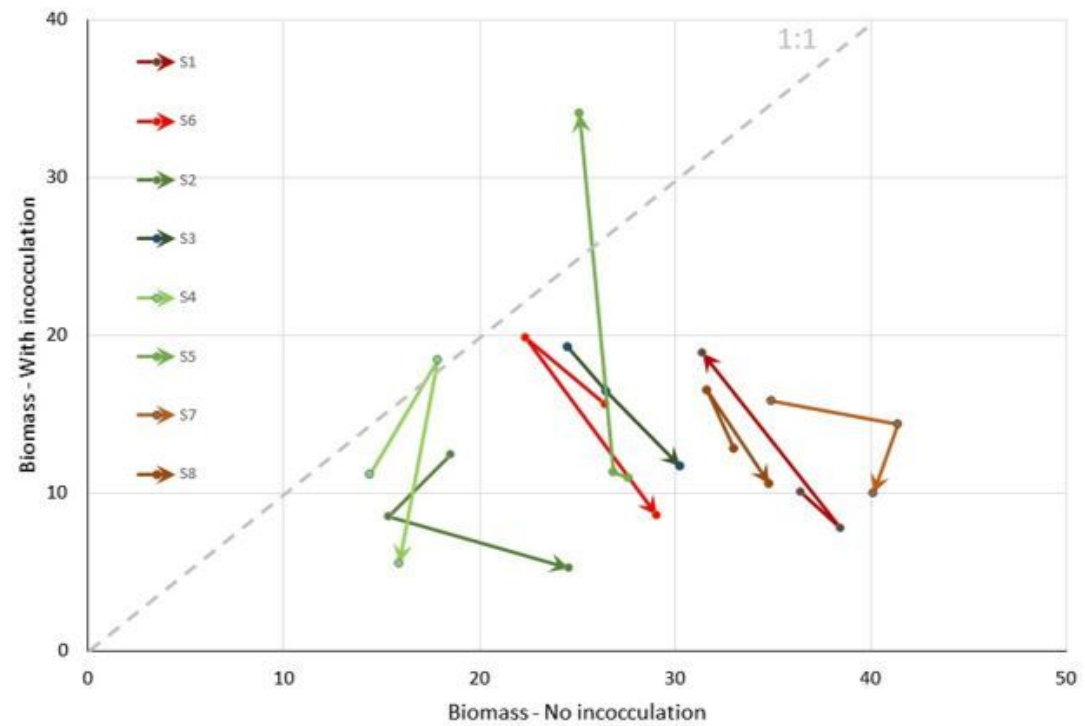

\section{Figure 5}

The effect of increases in soil Nitrogen on the effect of Fusarium wilt (Foc Race 1) on the leaf area of Gros Michel banana plants (Musa AAA) in a pot experiment with 8 soil types from Costa Rican banana region. The arrows represent the effect of increases in Nitrogen concentration (representing fertilization).

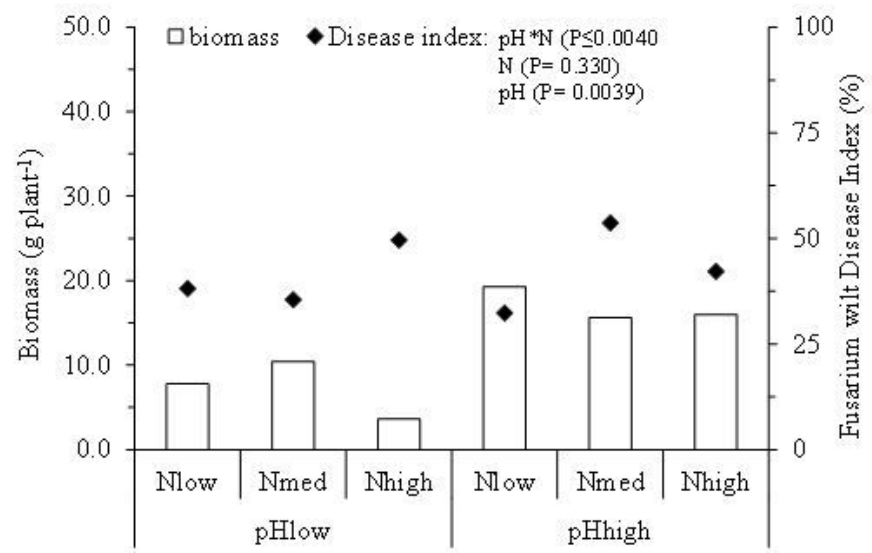

\section{Figure 6}

Average biomass (g) and wilting (\%) of inoculated ( $\ln 1)$ Gross Michel banana plants (Musa AAA) grown in eight Costa Rican banana soils types according pH levels (low and high) and $\mathrm{N}$ doses (Nlow, Nmed and Nhigh).

\section{Supplementary Files}

This is a list of supplementary files associated with this preprint. Click to download.

- formulas.docx

- seguraetal2021DATASET.xlsx 